\title{
Reability investigations of bacteriological aspects of play dough
}

\section{Oyun hamurlarının bakteriyolojik açıdan güvenilirliğinin araștırılması}

\author{
Görkem DÜLGER ${ }^{1}$, Emel ÇALIŞKAN² ${ }^{2}$, Nida KILIÇ², Handan ANKARALI ${ }^{3}$
}

\begin{abstract}
Objective: The aim of this study is to microbiologically evaluate the play doughs sold in stationery shops in Düzce province and frequently used in preschool education institutions.

Methods: 50 samples from five different containers that belong to ten different companies were included in the study. Each of the containers was evaluated six times as pre-play, first day post-play, first week postplay, second week post-play, third week post-play and fourth week post-play in terms of bacteriological reproduction. One gram of each play dough sample was added to the Brain Heart Infusion Broth (BH) (Oxoid) medium and incubated at $37^{\circ} \mathrm{C}$ for 24 hours. Blood Agar and Eosin Methylene Blue Agar (Becton Dickinson, USA) were inoculated from $\mathrm{BH}$ and incubated at 37 - C for 18-24 hours. Firstly, Gram stain was used in the identification of the bacteria in the samples after the incubation. Afterwards, the conventional methods such as catalase test, glucose test, nitrat test, voges proskauer test and Phoenix 100 BD automatize system (Becton Dickinson Diagnostic Systems, Sparks) were used. Z-test was used to determine the growth in preplay and post-play period statistically for differences between two dependent proportions.
\end{abstract}

\section{ÖZET}

Amaç: Bu çalıșmada; Düzce ilinde bulunan kırtasiyecilerde ve okul öncesi eğitim veren kurumlarda sıklıkla kullanılan oyun hamurlarının mikrobiyolojik açıdan değerlendirilmesi amaçlanmıştır.

Yöntem: On farklı firmaya ait beș farklı kutudan toplam 50 örnek çalıșmaya dahil edilmiștir. Kutuların her biri bakteriyolojik üreme açısından, oyun öncesi, oyun sonrasındaki birinci gün, birinci hafta, ikinci hafta, üçüncü hafta ve dördüncü haftada olmak üzere altışar kez incelenmiștir. Oyun hamuru örneklerinin her birinden birer gram Brain Heart Infusion Broth $(\mathrm{BH})$ (Oxoid) besiyerine eklenmiș ve $37{ }^{\circ} \mathrm{C}$ 'de 24 saat inkübasyona tabi tutulmuștur. BH'de gelișen kolonilerden Kanlı Agar ve Eosin Methylene Blue Agar (Becton Dickinson, USA) besiyerlerine ekim yapılarak $18-24$ saat $37{ }^{\circ} \mathrm{C}$ ' de inkübasyona bırakıımıștır. İnkübasyon sonrası üremenin gerçekleștiği örneklerdeki bakterilerin tiplendirilmesinde ilk önce Gram boyama, ardından katalaz testi, glikoz testi, nitrat testi, Voges Proskauer testi gibi konvansiyonel yöntemler ile Phoenix 100 BD otomatize sistem (Becton Dickinson Diagnostic Systems, Sparks) kullanılmıștır. Oyun öncesi ve sonrası dönemlerdeki üremelerin istatistiksel olarak belirlenmesinde iki bağımlı oran arasındaki farka ait Z-testi kullanılmıștır.

'Duzce University, Faculty of Medicine, Department of Medical Biology, Duzce, Turkey

${ }^{2}$ Duzce University, Faculty of Medicine, Department of Medical Microbiology, Duzce, Turkey

${ }^{3}$ Duzce University, Faculty of Medicine, Department of Biostatistics, Duzce, Turkey

İletişim/ Corresponding Author: Emel ÇALIŞKAN

Duzce University Faculty of Medicine Department of Medical Microbiology, Duzce - Turkey

Tel : +905352640114 E-posta/E-mail : emelcaliskan81@yahoo.com.tr

DOI ID : 10.5505/TurkHijyen. 2016.34603

Dülger G, Calıșkan E, Kılıc N, Ankaralı H. Reability investigations of bacteriological aspects of play dough.

Turk Hij Den Biyol Derg, 2017; 74(1): 29-36 
Results: The analysis showed that while no growth was observed in any culture of two companies (20\%) out of 10 , there was a growth in all cultures of the two products. As a result of the analysis, it was determined that all observed bacteria were Bacillus licheniformis and Bacillus cereus that belong to Bacillus genus. It was found that 51 (33\%) of all Bacillus were B. Licheniformis, and 104 (67\%) of them were B. cereus. As a result of the post-play culture study, it was observed that bacterial uremia decreased in play dough although it was not statistically significant until the fourth week from one day.

Conclusion: Pathogens can cause health problems such as food poisoning and eye infections. Moreover, preschool children on the market have the ability to move the hand muscles to the dangerous dimensions of having the edible label on most of the play dough that are used for educational purposes and often in educational instutions. Besides, according to the literature review, it is emphasized for the first time in this study that the bacteriological safety is an important issue for children's health in our country.

Key Words: Bacillus cereus, Bacillus licheniformis, play dough
Bulgular: Yapılan incelemede on firmadan ikisinin (\%20) hiçbir kültüründe üreme olmadığı tespit edilirken iki firmanın çalıșmaya dahil edilen tüm kültürlerinde üreme olduğu bulunmuștur. Doğrulama sonucunda üreyen tüm bakterilerin Bacillus cinsine ait olduğu görülmüștür. Bacillus'ların 51 (\%33)'inin Bacillus licheniformis, 104 (\%67)'ünün Bacillus cereus olduğu belirlenmiștir. Oyun sonrası yapılan kültür çalıșması sonucunda ise birinci günden itibaren dördüncü haftaya kadar istatistiksel olarak anlamlı olmasa da oyun hamurlarında bakteriyel üremenin bir miktar azaldığı görülmüștür.

Sonuç: Üreyen bakterilerin bașta gıda zehirlenmesi ve göz enfeksiyonları olmak üzere ciddi sağlık problemlerine sebebiyet verdiği ve piyasada bulunan, okul öncesi çocukların el kaslarının gelișmesi amacı ile sıklıkla eğitim veren kurumlarda kullanılan oyun hamurlarının çoğunun üzerinde de yenilebilir ibaresinin bulunması, durumu daha da tehlikeli boyutlara taşıyabilmektedir. Ayrıca, yapılan literatür taramasına göre, ülkemizde çocuk sağığı için önemli bir konu olan oyun hamurlarının bakteriyolojik açıdan güvenilirliği ilk kez bu çalıșmada vurgulanmaktadır.

Anahtar Kelimeler: Bacillus cereus, Bacillus licheniformis, oyun hamuru

\section{INTRODUCTION}

Endospore forming bacteria can be mesophilic, aerobic and are often available in raw vegatables in high quantity. They cause spoilage and toxicity problems. (1). The bacteria belonging to Bacillus genus are generally soil borne. The sizes of Bacillus bacteria can range from $(0.5 \mu \mathrm{m}-1.2 \mu \mathrm{m})$ to $(2.5 \mu \mathrm{m}-10 \mu \mathrm{m})$. Bacillus species are aerobe and facultative anaerobe, Gram positive, mobile and do not contain spores (2). Bacillus megaterium in particular, Bacillus subtilis, Bacillus licheniformis, Bacillus megaterium, Bacillus pumilus and
Bacillus cereus can cause certain problems called as "ropiness" by developing in products especially made of wheat due to the spores being resistant to heat (3). Ropiness which occurs in especially breads during summer months is an important problem caused by some sporophyte bacteria. $B$. subtilis spores are found in flour and barely in yeast which is used for baking bread (4). The flours produced from wheat whose sterilization are not paid attention have a high possibility to contaminate with Bacillus bacteria. Besides, it is 
possible that spores can settle on bread because of added substances such as yeast and flour used for baking bread, lack of water and insufficient hygienic conditions (5).

As a result of the studies done by the scientist recently, it is stated that Bacillus species have caused serious spoilage in food (2). It is also stated that dairy products especially contaminated with psychrotroph serotypes of $B$. cereus are risky for public health, and that psychrotroph serotypes form toxin by multiplying during the process of preserving dairy products in cold (4). Preservatives such as calcium propionate, acetic acid, propionate acid are used with the purpose of inhibition of Bacillus bacteria in food, especially flour products (3).

It is reported that many Bacillus species have caused severe infection in eyes due to its contamination with dust and soil. It is stated that $B$. licheniformis, $B$. cereus, $B$. subtilis, $B$. brevis and $B$. sphaericus (6). There are enzymes such as necrotising exotoxin, emetic toxin, hemolysin, lecithinase and protease among pathogenicity factors of $B$. cereus. The most common contagious diseases which the bacteria cause is food poisoning existing in two different types as "emetic" and "diarrheal". Moreover, eye infections such as posttraumatic endophthalmitis, keratitis, panophthalmina; burn, wound and skin infections; meningitis and lower respiratory tract infections can cause endocarditis, bacteraemia and sepsis (6). It was also reported in the studies previous that fever caused by the septicaemia of B. licheniformis - a kind of pathogen- or toxins are responsible of sepsis with trembling, peritonitis, corneal ulcer and eye infections (3).

In this study, it was aimed to determine the bacteriological quality level of play dough which have "antimicrobial" label on their wrappings in bookstores.

\section{MATERIAL and METHOD}

\section{Gathering Play Dough Samples}

Play dough samples were taken from ten different companies which were sold in some bookstores in Düzce province. In order to determine play dough's microbiological quality play dough were brought into the laboratuar under the proper conditions such as paying attention not to make their package open. The play dough were kept at room temperature.

\section{Searching Bacteria in Play Dough}

In total 50 samples from five different containers of ten different companies were included in the study. Each of the containers was evaluated in six times as pre-play, first day post-play, first week post-play, second week post-play, third week post-play and fourth week post-play in terms of bacteriological growth. Containers are opened for the first time in a biological safety cabinet for preplay review. The pieces taken from play dough via sterilized swabs were added to $10 \mathrm{~mL}$ Brain Heart Infusion Broth (Oxoide) and were preserved at $37^{\circ} \mathrm{C}$ for 24 hours. Later, the incubation was applied at $37^{\circ} \mathrm{C}$ for $18-24$ hours by inoculating into Blood Agar from Brain Heart Infusion Broth and EMB Agar (Becton Dickenson, USA).

Firstly Gram staining, later conventional methods such as catalase test, glucose test, nitrat test, Voges Proskauer test were implemented in the process of identifying the bacteria in the samples the growth was monitored. Finally, the identification was carried out Phoenix 100 BD automatize system (Becton Dickinson Diagnostic Systems, Sparks).

\section{Statistical Analysis}

The descriptive values which belong to the acquired datum was stated as number and \% frequency in the table. Z-testi (also referred to as McNemar test) which belongs to the difference among two dependent samples' rate was used for observing the differences in terms of the frequency of biogenic species during the days when the 
measurement was done and the frequency of growth in total. Microstat (DOS version) program was used for statistical analysis and mistake possibility was accepted as 5\%. Hypothesis were checked doublesided. $\mathrm{P}$ value less than 0.05 was considered significant.

\section{RESULTS}

No growth was detected in any culture of the two $(20 \%)$ of ten companies which were tested in the study. However, in all samples of two products Bacillus spp. growth was detected. Another type of bacteria did not appear. Of all culture prepared in pre-play period, $B$. cereus was detected in 18 (36\%), $B$. licheniformis was detected in $9(18 \%)$. It was found that 51 (33\%) of all growthing Bacillus genus was $B$. licheniformis and 104 (67\%) of them was B. cereus (Figure 1). The distribution of the detected bacteria was showed in Table 1 according to the incubation period. Besides, it was observed that Bacillus species formed colonies by using play dough like its broth in 24 hours when the play dough, whose package had been opened for the first time, from which samples had been acquired, in which Bacillus species growth in their incubation were kept at suitable temperature and aerobe conditions (Figure 2). Growth was observed again in the samples after play. In the observation done, that $B$. cereus in $19(38 \%)$ samples and $B$. licheniformis in $9(18 \%)$ samples at the end of the first day, B. cereus in 19 (38\%) samples and $B$. licheniformis in $9(18 \%)$ samples at the end of the first week, B. cereus in $18(36 \%)$ and B. licheniforis in $9(18 \%)$ samples at the end of the second week, B. cereus in $15(30 \%)$ samples and B. licheniformis in $8(16 \%)$ samples at the end of the third week, $B$. cereus in 15 (30\%) samples and B. licheniformis in 7 (14\%) samples at the end of the fourth week were determined. In both species it was observed that there was a decrease in prevalence depending on time; however, in consequence of statistical evaluations it was found out that a significant difference did not occur between the first day after play when the most variation had happened and the third or fourth week after play when considered of the total growth frequency in both species (the variation: $p=0.4906$ for $B$. cereus, and $p=0.6120$ for $B$. licheniformis). $P$ values in the other comparisons were found higher. This result shows that it is not a variation in the level which can be called statistically as "meaningful" while there is a noticeable decrease in growth. 
Table 1. Distribution of number of samples bacteria growth dependent on the time

\begin{tabular}{|c|c|c|c|c|c|c|}
\hline Bacteria & P.P. & $\begin{array}{l}\text { A.P. } \\
\text { 1. day }\end{array}$ & $\begin{array}{l}\text { A.P. } \\
\text { 1. Week }\end{array}$ & $\begin{array}{l}\text { A.P. } \\
\text { 2. Week }\end{array}$ & $\begin{array}{l}\text { A.P. } \\
\text { 3. week }\end{array}$ & $\begin{array}{l}\text { A.P. } \\
\text { 4. week }\end{array}$ \\
\hline Bacillus cereus & $18(36 \%)$ & 19 (38\%) & 19 (38\%) & 18 (36\%) & 15 (30\%) & 15 (30\%) \\
\hline $\begin{array}{l}\text { Bacillus } \\
\text { licheniformis }\end{array}$ & $9(18 \%)$ & $9(18 \%)$ & $9(18 \%)$ & $9(18 \%)$ & $8(16 \%)$ & 7 (14\%) \\
\hline $\begin{array}{l}\text { Frequency of Total } \\
\text { Growth }\end{array}$ & 27 (54\%) & $28(56 \%)$ & $28(56 \%)$ & 27 (54\%) & $23(46 \%)$ & 22 (44\%) \\
\hline $\begin{array}{l}\text { Total Sample } \\
\text { Frequency without } \\
\text { Growth }\end{array}$ & $23(46 \%)$ & $22(44 \%)$ & 22 (44\%) & $23(46 \%)$ & 27 (54\%) & $28(56 \%)$ \\
\hline $\begin{array}{l}\text { Total Sample } \\
\text { Number }\end{array}$ & 50 & 50 & 50 & 50 & 50 & 50 \\
\hline
\end{tabular}




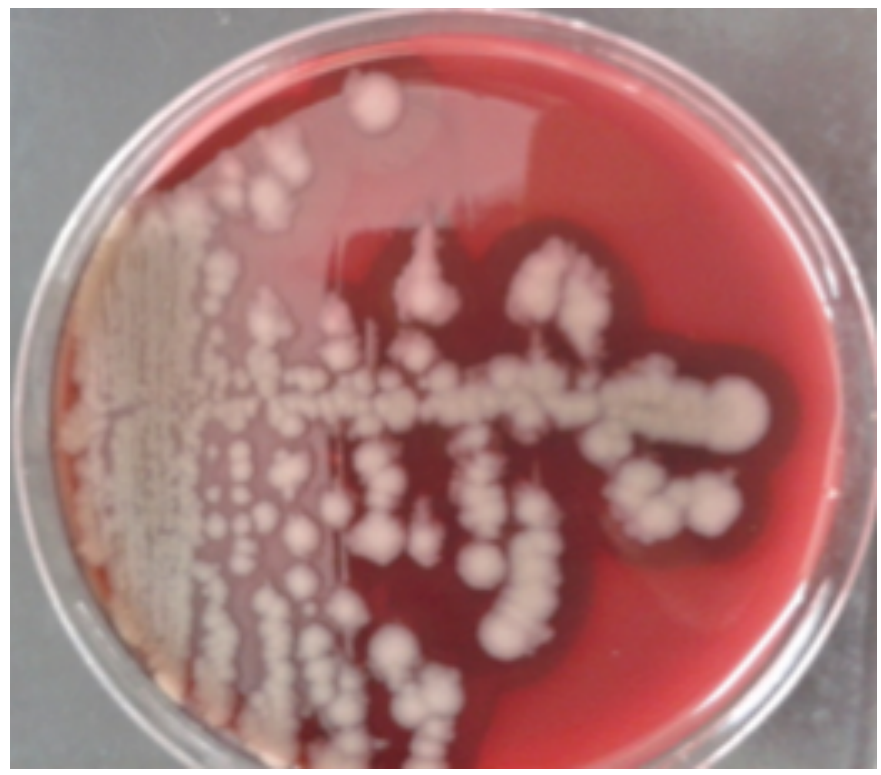

Figure 1. B. cereus colonies isolated from play dough on blood agar

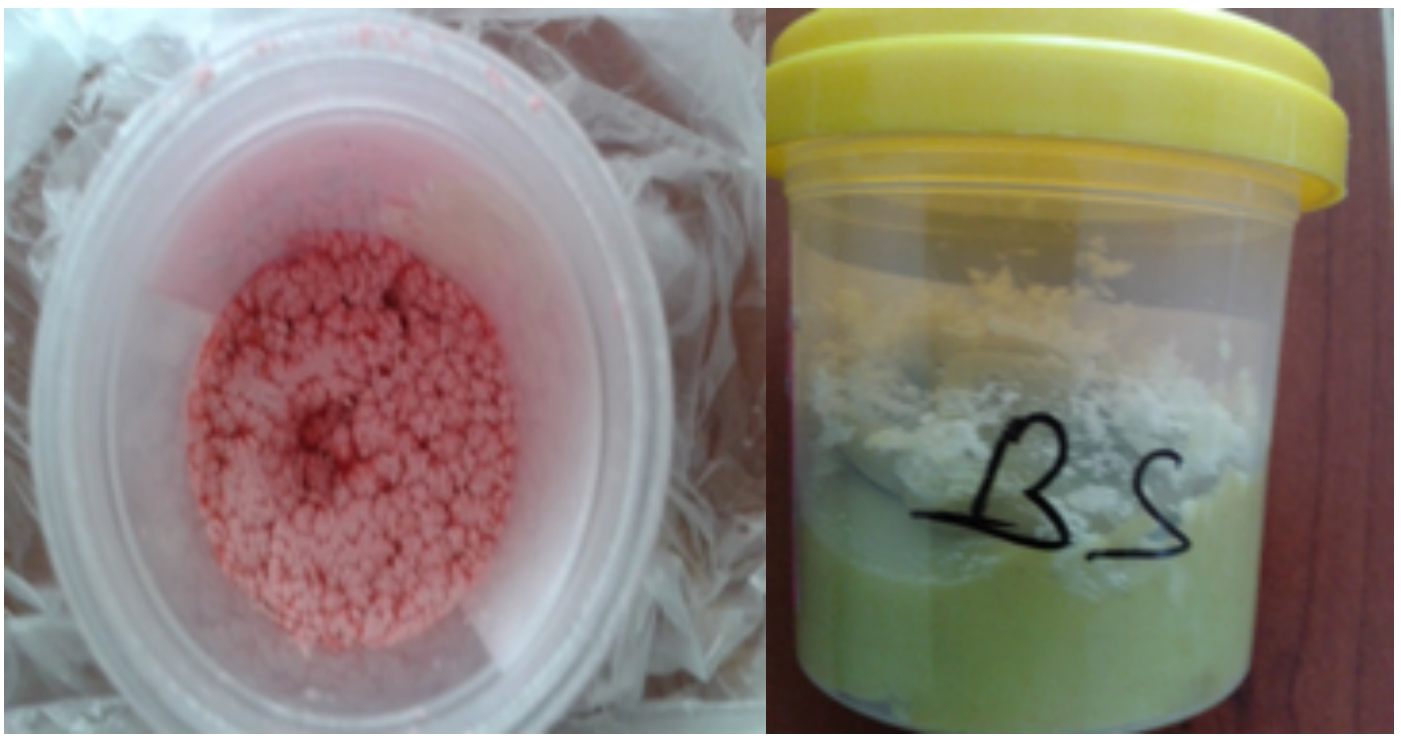

Figure 2. B. cereus colonies isolated from play dough at ambient temperature 


\section{DISCUSSION}

Bacillus species, which is soil borne and has spores resistant to heat and hard conditions, can keep their growing in many food products particularly whose raw material is flour. In this study it was observed that Bacillus species could growth even in the minimal food media easily in play dough whose basic gradient is wheat gluten. In the samples of before-play and after-play periods no difference was found statistically with regard to bacteria growth, and it was observed that bacteria growth started to decrease since the after-play third week. It was thought that the growth rate would decrease over time depending on bacteria's devouring food source.

Since the past years food poisonings which occurs through Bacillus spp. endospore in cerealbased food products have often been seen (7). Bacillus species lead to contamination in especially raw or unprocessed food products (8). It was stated that $B$. licheniformis caused bread ropiness and foodborne diseases (9). It was also stated that pathogenic $B$. cereus which often cause humanbeing to get infection lead to food emetic poisoning and (toxico-infection) infections like diarrhoea (8). Toxico infections derive from $\mathrm{Hbl}$ toxin which is created in intestine by microorganism, Nhe toxin and Sitotoxin $\mathrm{K}$ action $(8,10)$. In another study, it was reported that $B$. cereus, B. subtilis and $B$. licheniformis lead to endophthalmitis which occurs due to the invasion of intraocular tissue (11). This situation emphasizes that if hygiene conditions are not paid enough attention eye infections are likely to occur as a result of the frequent-contact of preschool children who we talked about in our study with play dough. Likewise, if a bacterial growth in play dough is in question, it must not be ignored that certain infections can develop because of the fact that a child may swallow play dough or put his/her hand in his/her mouth. According to the literature reviews, in this study it was the first time to emphasize that $B$. cereus and $B$. licheniformis which both belong to Bacillus genus growth in play dough.

The detection of $B$. cereus species which especially causes food poisoning in play dough makes us think that it can cause infection in case children swallow play dough or put their hands in their mouth. B. licheniformis which is another detected species can be risky for children health because it can cause lots of diseases such as conjunctivitis. As a consequence, it was found out that some of the play dough is not bacteriological safe that companies should pay ultimate attention to prevent bacterial contamination, that antimicrobial material used during production period should be reformulated, and it is considered that supervisions about this situation should be increased. 


\section{REFERENCES}

1. Viedma PM, Abriouel H, Omar NB, Lopez RL, Galvez A. Inhibition of spoilage and toxigenic Bacillus species in dough from wheat flour by the cyclic peptide enterocin AS-48. Food Conrol, 2011; 22 (5): 756-61.

2. Willke TA, Söyletir G, Doğanay M. Enfeksiyon Hastalıkları ve Mikrobiyolojisi. 3. baskı. İstanbul: Nobel Tip Kitabevleri, 2008; 399-424.

3. Var I, Zorlugenç B, Kabak B, Uzunlu S. Un, ekmek ve yaș pastalarda rop hastalığına neden olan Bacillus sporlarının incelenmesi. Dünya Gıda, 2012; 2: 748.

4. Arslan S, Erginkaya Z, Özaslan M, Kılıç HI, Ünal E. LactoBacillus rhamnosus 'un sünme (rope) hastalığı etkeni olan Bacillus cinsi bakteriler üzerine inhibitör etkisinin unlarda araștırılması. Türk Mikrobiyol Cem Derg, 2013; 43 (4): 155-64.

5. Certel M, Erem F, Karakaș B. Farklı depolama koșullarında normal ve kepekli ekmeklerin mikrobiyolojik özellikleri, su aktivitesi ve sünme durumunun değișimi. Gıda, 2009; 34 (6): 351-8.

6. Mengeloğlu ZF, Terzi HA, Bilici M. Kateter kaynaklı Bacillus cereus bakteriyemisi olgusu ve izolatlar arasındaki klonal ilișkinin PFGE ile araștırılması. Dicle Tip Derg, 2011; 38 (3): 358-60.
7. Granum PE. Bacillus cereus. In: Doyle MP, Beuchat LR, eds. Food Microbiology. Fundamentals and Frontiers. 3rd edn. Washington. ASM Press, 2007. pp: 445-55.

8. Pluata $A B$, Pluata A, Garbowska M. The effect of selected factors on the survival of Bacillus cereus in the human gastrointestinal tract. Microb Pathog, 2015; 82: 7-14.

9. Kramer JM, Gilbert RJ. Bacillus cereus and other Bacillus species. In: Doyle MP, ed. Foodborne bacterial pathogens. New York. Marcel Dekker, 1989: 22-70.

10. Beecher DJ, Olsen TW, Somers EB, Wong AC. Evidence for contribution of tripartite hemolysin $\mathrm{BL}$, phosphatidylcholine-preferring phospholipase $\mathrm{C}$ and collagenase to virulence of Bacillus cereus endophthalmitis. Infect Immun, 2000; 68(9): 526976.

11. Bhagat $N$, Nagori S, Zarbin M. Post-traumatic infectious endophthalmitis. Surv Ophthalmol, 2011; 56 (3): 214-51. 